\title{
EFFECT OF CONIOTHYRIUM MINITANS AND TRICHODERMA HARZIANUM IN THE BIOLOGICAL CONTROL OF WHITE MOLD DISEASE (SCLEROTINIA SCLEROTIORUM) IN LETTUCE (LACTUCA SATIVA L.)
}

\author{
ÇOLAK ATEŞ, A. \\ Biological Control Research Institute, Department of Phytopathology, Adana, Turkey \\ e-mail: aysegulcolak@hotmail.com; phone: +90-322-344-1784 \\ (Received $29^{\text {th }}$ Aug 2019; accepted $15^{\text {th }}$ Nov 2019)
}

\begin{abstract}
Sclerotinia sclerotiorum (SC) is one of the most destructive soil-borne diseases in lettuce cultivation. In the present study, the effectiveness of single and combined use of Coniothyrium minitans (C) and Trichoderma harzianum (TH) as biological alternative to chemical SC control was investigated in two lettuce fields in the 2018-2019 production seasons in the province of Mersin/Turkey. In both lettuce trial plots, it was determined that the SC disease rates under single and combined use of $C$ and TH were significantly reduced when compared to both the control and application of chemical fungicide that contained active substances Fluopyram + Pyrimethanil (Luna Tranquility). In all parcels where the biological preparations were applied alone and in combination, the obtained results suggest that these treatments may be a viable alternative to chemical methods. Thus, the highest impact on SC in both lettuce trial fields was $80-86.05 \%$ in $\mathrm{C}(4 \mathrm{~kg} / \mathrm{ha})+\mathrm{TH}$ combination, while the lowest effect was obtained of only TH application with $54-60.47 \%$. Analysis of the lettuce plant yield demonstrated that the application led to a significant increase in the yield in all lettuce cultivation fields when compared to control. The increase in yield ranged between $13-34 \%$ and $16-27 \%$ in the experimental fields and the highest increase was obtained with Coniothyrium minitans $(4 \mathrm{~kg} / \mathrm{ha})+$ Trichoderma harzianum coadministration.
\end{abstract}

Keywords: Biological control agent, Lactuca sativa L., Sclerotinia sclerotiorum, Trichoderma harzianum, yield

\section{Introduction}

Lettuce (Lactuca sativa L.), which is a popular agricultural produce worldwide, is a cool climate vegetable that plays an important role in human nutrition. China is the leader in lettuce production followed by the USA, India and Spain, respectively. Different varieties are produced in different regions in Turkey with open field and greenhouse cultivation of this vegetable varieties with edible leaves. Turkey is the eighth largest lettuce producer in the world with 419066 tons according to FAO statistics (Anonymous, 2017). In Turkey, lettuce farming is most popular in the Mediterranean, Marmara and Aegean regions.

The fungal diseases reduce the market value in the cultivation of lettuce, which has a rich nutritive value. Sclerotinia sclerotiorum is the most important and most common cause of fungal diseases that lead to major problems in lettuce cultivation fields. $S$. sclerotiorum, a soil-borne pathogen, is a member of Sclerotiniaceae family of the Helotiales group of the Discomycetes class. The host sequence of the disease agent is quite extensive and it leads to root, trunk and fruit rot in about 400 plant species (Purdy, 1979; Elshestawi et al., 2017; Smolinska and Kowalska, 2018). The disease agent spends the winter as sclerotium in the soil or in plant residues. The $S$. sclerotiorum sclerotia, which are prevalent in temperate regions, were recorded to survive in the soil for more than 10 years (Adams and Ayers, 1979; Clarkson et al., 2004). It was reported 
that the product losses due to white mold disease caused by Sclerotinia sclerotiorum agent were up to 95\% worldwide and in Turkey (Purdy, 1979; Young et al., 2001; Hao and Subbarao, 2005; Chitrampalam et al., 2010). It was reported that the crops are completely lost in completely infected fields and loses its market value due to losses in crop size and weight in partially infected fields (Clarkson et al., 2014).

In several studies conducted on the control of Sclerotinia sclerotiorum disease agent, it was reported that fungicide use harms the environment, as well as the reliability of the products consumed fresh, and increased the tolerance of the diseases against fungicides. In several studies, it was reported that mycoparasite fungi were effective against Sclerotinia diseases. Among these, Coniothyrium minitans and Trichoderma spp. are the most commonly used species (Turner and Tribe, 1976; Whipps and Budge, 1990; Budge and Whipps, 1991, 2001; Jones and Whipps, 2002). In the control of sclerotia diseases, it was emphasized that biological preparations were extremely important, since their action paths are not similar to fungicides and they directly destroy the sclerotia in the soil (Porter et al., 2002; Villalta et al., 2012). C. minitans produces secondary metabolites such as macrosphelide A, benzo furanones and chromans, which increase the colonization and degradation of $S$. sclerotiorum sclerotia and a wide range of cell wall degrading enzymes such as chitinases and glucans (Giczey et al., 2001; Tomprefa et al., 2011). Trichoderma fungi are highly competitive when compared to other soil-borne microorganisms due to its rapid growth and abundant spore production. The ability to secrete active compounds differs significantly among Trichoderma species and isolates. Thus, the mechanisms used by Trichoderma spp. in biological control vary based on the species, the pathogen and the host plant. In the case of antifungal activity against $S$. sclerotiorum, Trichoderma's mycoparasite properties play an important role. Trichoderma enzymes that break down the cellular wall of the pathogens were identified as chitinases, glucans, proteases and cellulases (Qualhato et al., 2013; Lopez-Mondejar et al., 2011; Naher et al., 2018). It was reported that Trichoderma species may be an important factor in the induction of plant growth and yield, as well as the control of plant phytopathogenic fungi in various plant species (Vinale et al., 2008; Bal and Altıntaş, 2008; Çolak, 2007; Çolak and Biçici, 2013; Elias et al., 2016).

Several studies were conducted globally that aimed to discover alternatives to fungicides in sclerotia diseases. Porter et al. (2002) preferred control with biological preparations in the control of Sclerotinia diseases and utilized Coniothyrium minitans and Trichoderma spp. species. Their findings were more successful when compared to fungicidal and Metham sodium applications. Villata et al. (2012), in a study conducted with biological preparations of T. hamatum 6sr4, C. minitans A69 and C. minitans in lettuce, reported that biocontrol agents could be used as an effective management tool against $\mathrm{S}$. minor, the factor for white mold disease, in lettuce cultivation. Matheron and Porchas (2003) used Boscalid and Iprodion in lettuce cultivation fields against $S$. sclerotiorum and S. minor, which lead to white rot disease, while Coniothyrium minitans (Contans) was used as biological control agent. It was reported that their effectiveness was $33-38 \%$ and $52 \%$, respectively in lettuce fields contaminated with $S$. sclerotiorum, and 53-35-32\%, respectively in S. minor infected fields. Chitrapalam et al. (2008) conducted a two-year field study at Yuma County to investigate the effects of several biological agents against the disease induced by Sclerotinia species. Commercial formulations of biological preparations such as Trichoderma harzianum (Plantshield, Supersivit), Gliocladium virens (Soilgard), Coniothyrium minitans (Contans) and 
Bacillus subtilis (Companion), and a chemical fungicide, Iprodione (Rovral) were evaluated and compared against Sclerotinia sclerotiorum and S. minor. In the study, it was found that using the preparations once was not sufficient, however it was determined that the severity of the disease decreased when the administrations were conducted twice. At the end of the study, Coniothyrium minitans (Contans) biological preparation provided the most effective control against Sclerotinia sclerotiorum.

The preparation that contains Coniothyrium minitans isolate is a mycoparasite fungus species that was not certified in Turkey, however used successfully in the control of white mold disease in the USA and G8 countries with the commercial brand of Contans WG in greenhouses and fields. However, in Turkey, no studies were conducted to assess the success criteria for these biological preparations in the control of white mold disease induced by Sclerotinia sclerotiorum in lettuce fields (Anonymous, 2017). In Turkey, several studies were conducted on the prevalence of $S$. Sclerotiorum disease agents, which determined the mycelial fitness groups (MFG), and in-vivo and in-vitro biological control opportunities (Çarkacı and Maden, 1986; Aksay et al., 1991; Mert-Turk and Mermer, 2004; Çolak, 2007; Çoşkun and Yildiz, 2017; Soylu et al., 2017). In studies on the prevalence of disease factor in lettuce conducted in Turkey, the prevalence was determined as $82.5 \%$ in Çanakkale (Mert-Türk and Mermer, 2004), 25-57.1\% in Hatay province and districts (Soylu et al., 2017), 3.3\% in Adana province Karataş district, $10.6 \%$ in Tarsus district and $4.6 \%$ in Osmaniye province (Çolak and Fidan, 2018). However, the studies on the control of the disease agent with biological control agents in the field are rather recent, and the effectiveness of the Coniothyrium minitans biological preparation on Sclerotinia sclerotiorum was investigated for the first time in the present study. Studies on the parasite effect on sclerotia and reduction of apothecia density of Trichoderma harzianum that we tested in control of $S$. sclerotiorum were mostly conducted in greenhouse and laboratory conditions (Bal and Altintaş, 2008; Geraldine et al., 2013; Smolinska et al., 2016). The number of studies on the antagonistic activity of Trichoderma in the field is very limited (Knudsen et al., 1991; Zeng et al., 2012a; Geraldine et al., 2013).

$S$. sclerotiorum is a disease agent difficult to control due to the resistant structures created by the disease agent in the soil. Currently, the losses due to the rapid degradation of the fungicides in the soil range between $5 \%$ and $40 \%$ in the control of the disease (Chitrampalan et al., 2011). The majority of the chemicals used in control aim to protect the parts of the host plant that are above the ground, especially the flowers, from ascospore infection. Thus, the application time should be carefully selected and the green parts should be covered with medication for an effective chemical control. In this context, due to the residual risks caused by the use of chemicals in control, the research on possibilities of biological control became popular in recent years. In biological control studies, it was observed that the studies mostly focused on the parasite infection of sclerotia mainly by mycoparasite fungi. The present study investigated the effectiveness of single and combined applications of Coniothyrium minitans and Trichoderma harzianum, which are biological agents alternative to chemical control, in the control of white mold disease (Sclerotinia sclerotiorum) that causes economic damages in lettuce cultivation. 


\section{Materials and methods}

\section{The study area}

Control experiments were set up under producer conditions in the study lettuce fields to determine the effectiveness of Coniothyrium minitans (strain CON/M/91-08, $1 \times 10^{12}$ CFU/kg, Contans, Bayer) and Trichoderma hazianum (Trichoderma harzianum Rifai race KRL-AG2 (TH, T-22 Planter Box, 1x10 CFU/g, Bioglobal) biological preparations against white mold disease. Yonca 80 lettuce variety was used as material. For this purpose, field experiments were set up in two lettuce fields in Mersin province Kazanlı (KA) and Demirhisar (DE) regions that are naturally inoculated and in which the disease was prevalent in the previous cultivation season in the 2018-2019 cultivation season. However, for homogenous distribution of the disease agent in all experiment plots, artificial inoculation $\left(25 \mathrm{~g} / \mathrm{m}^{2}\right)$ was conducted with Sclerotinia sclerotiorum (SC) after the soil was plowed and ready for seeding. For this purpose, SC region isolate obtained from lettuce plant was used in field trials. The SC isolate was incubated in PDA for 10 days at $25^{\circ} \mathrm{C}$ and the disks obtained from the SC isolate were inoculated to humidified and sterilized wheat medium (1000 g wheat $+800 \mathrm{ml}$ water) in Erlenmeyer flasks and allowed to incubate another 10 days at $25^{\circ} \mathrm{C}$. The inoculum developed in the incubation was broken down and $25 \mathrm{~g}$ was applied per 1 square meter experimental soil. Then the soil was processed with a rotovator at a depth of $5-10 \mathrm{~cm}$ to allow homogenous distribution of the inoculum in the soil (Chitrampalam et al., 2008; Elshestawi et al., 2017). Lettuce seedlings were planted in the fields of sandy loam soil structure in a distance of $40 \mathrm{~cm}$ on the row and between rows. The experiment was designed in 4 replicates for each application and 20 lettuce plants per replicate (total 80 plants) based on randomized blocks experimental design.

\section{Biological preparation and fungicide application}

Coniothyrium minitans and Trichoderma harzianum biological preparations were applied to the soil via absorption immediately after the lettuce seedlings planted. Biological preparations were applied to the plant for the second time as recommended in the thinning period after the initial single and combined applications. For this purpose, Coniothyrium minitans (C) biological preparation was applied in recommended three doses (C2: $2 \mathrm{~kg} / \mathrm{ha}, \mathrm{C} 3: 3 \mathrm{~kg} / \mathrm{ha} ; \mathrm{C} 4: 4 \mathrm{~kg} / \mathrm{ha})$, while Trichoderma harzianum $(\mathrm{TH})$ biological preparation was applied in the recommended $(50 \mathrm{~g} / 100 \mathrm{lt} / \mathrm{T}$ 22) dose. In the study, Luna Tranquility SC (125 g/L Fluopyram + $375 \mathrm{~g} / \mathrm{L}$ Pyrimethanil/SC, Bayer) was used as a chemical fungicide which was used extensively in Sclerotinia sclerotiorum control in lettuce fields. Luna Tranquility SC was applied once in the thinning period on green sections in a single dose of $100 \mathrm{lt} / \mathrm{da}$ as recommended in manufacturer's instructions (Table 1). A row of safety lanes was left between the application plots. The control plot plants were applied only water (without biological preparat and fungicide) (Elsheshtaewi et al., 2017). In the harvest, the plants were evaluated as sick and healthy.

At the end of the count, percentage of infected and non-infected plants were determined among the plants divided as sick and healthy and the percentage of the impact of the treatments were evaluated with Abbott's formula $(\%$ effect $=[\operatorname{control}(\%)$ - application $(\%) /$ control $(\%)] \times 100)$ and statistical analyzes were conducted (Karman, 1971). The analyses of variance and mean values were compared with the LSD test (P: 0.05). 


\section{Determination of the effect of applications on the yield and certain physical properties}

In the study, when the lettuce in the experimental fields were ready for harvest, 10 plants were removed from each replicate to represent the average in all application plots and mean marketable head weight ( $\mathrm{kg} / \mathrm{plant})$, root weight $(\mathrm{g})$, root length and crown diameter $(\mathrm{mm})$ were measured. After the weights of the plants harvested from each plot were determined, the mean plant weight $(\mathrm{kg} / \mathrm{plant})$ and parcel yield $(\mathrm{kg} / \mathrm{da})$ were calculated. For this purpose, marketable head weight (kg/plant) was determined after poor quality leaves and the roots were removed using precision scales. Crown diameter (mm) was measured by a digital caliper (SC Mitutoyo, Japan), which was sensitive to $0.02 \mathrm{~mm}$, using the plants harvested from inoculated fields. Mean root length $(\mathrm{cm})$ and weight $(\mathrm{g})$ were determined by measuring from the crown $(\mathrm{cm})$ and by weighing with a precision scale $(\mathrm{g})$ after the plants were harvested and washed without damaging the roots (Tüzel et al., 2011).

Table 1. Information on products tested against white mold disease in lettuce

\begin{tabular}{c|c|c|c}
\hline Active ingredient & Product name & Formulation type & Application rate \\
\hline $\begin{array}{c}\text { Coniothyrium minitans } \\
\left(\text { strain CON/M/91-08, } 1 \times 10^{12} \mathrm{CFU} / \mathrm{kg}\right)\end{array}$ & Contans & Wettable granule-WG & $2-4 \mathrm{~kg} / \mathrm{ha}$ \\
\hline $125 \mathrm{~g} / \mathrm{L}$ Fluopyram $+375 \mathrm{~g} / \mathrm{L}$ Pyrimethanil & $\begin{array}{c}\text { Luna } \\
\text { Tranquility }\end{array}$ & $\begin{array}{c}\text { Suspension } \\
\text { concentrate-SC }\end{array}$ & $100 \mathrm{ml} / \mathrm{da}$ \\
\hline $\begin{array}{c}\text { Trichoderma harzianum } \text { Rifai race KRL-AG2, } \\
1 \times 10^{7} \mathrm{CFU} / \mathrm{g}\end{array}$ & $\begin{array}{c}\text { T-22 Planter } \\
\text { Box }\end{array}$ & Wettable powder-WP & $50 \mathrm{~g} / 100 \mathrm{lt}$ \\
\hline
\end{tabular}

\section{Results and discussion}

\section{The effects of biological preparation applications on White mold disease}

The data obtained in the studies conducted to demonstrate the efficiency of single and combined use of biological agents Coniothyrium minitans and Trichoderma harzianum that are alternatives to chemical control of white mold disease (Sclerotinia sclerotiorum) that causes significant economic damages in the cultivation of lettuce, which is an edible vegetable are presented in Table 1. Table 1 demonstrated that the differences between the applications in both trial fields were statistically significant ( $\mathrm{P}<0.05)$. The disease infection rates in control plots in both lettuce trials were $62.50 \%$ and $53.75 \%$. It was observed that the rate of disease rate significantly decreased in both single and combined use of Coniothyrium minitans and Trichoderma harzianum when compared to both the control and chemical fungicide use. In this context, the lowest infected plant rate was $12.5 \%$ in $\mathrm{C} 4+\mathrm{TH}$ applied plots among the biological preparation applications in $\mathrm{SC}$ control when compared to control and pesticide applications and that was followed by C3 $(3 \mathrm{~kg} / \mathrm{da})+\mathrm{TH}$ and $\mathrm{C} 4(4 \mathrm{~kg} / \mathrm{da})$ applications (Table 1). Certain studies also reported that a combination of certain antagonists could lead to a higher level of protection, however improved control could not be observed in all cases (Spadaro and Gullino, 2005). The success of biological preparations could differ based on the soil type, type of biological agent, plant interactions and disease pathogen (Celar, 2002; Smolinska and Kowalska, 2018). It was reported that high soil moisture is important in degradation of the sclerotia in the soil by $C$. minitans (Trutmann et al., 1980). Budge et al. (1995) successfully integrated C. minitans and 
Trichoderma virens combinations in S. sclerotiorum control in greenhouse studies. The greatest decrease in the number and viability of sclerotia was obtained with the combination of $C$. minitans and Trichoderma virens in the second harvest, while in the third harvest the only significant reduction was achieved with $C$. minitans applications. In another study, T. harzianum T-22 isolate (PlantShield) protected the soybean against S. sclerotiorum and reduced the disease severity index by $38.5 \%$ in the field crops (Zeng et al., 2012a). Gerlagh et al. (1999) reported that mycoparasite $C$. minitans had the potential to keep soil contamination at low levels in crop rotations in various sclerotiorum-sensitive crops.

In the present study, the statistical analyzes conducted on the data obtained in KA plot trials demonstrated that the lowest infected plant rate was obtained with Luna $(11.25 \%), \mathrm{C} 4+\mathrm{TH}(12.50 \%)$ and $\mathrm{C} 3+\mathrm{TH}(15 \%)$ applications, while the highest infected plant rate was obtained with $\mathrm{TH}$ application $(28.75 \%)$. In DE plot, the lowest infected plant rate was obtained with Luna $(6.25 \%)$, $\mathrm{C} 4+\mathrm{TH}(7.50 \%)$ and $\mathrm{C} 3+\mathrm{TH}$ $(8.75 \%)$, while the highest infected plant rate was obtained with $\mathrm{TH}$ application $(21.25 \%)$. The most successful alternative to chemical applications was obtained with $\mathrm{C} 4+\mathrm{TH}$ application $(86.5 \%)$ in $\mathrm{DE}$ plots, followed by $\mathrm{C} 3+\mathrm{TH}$ and single $\mathrm{C} 4$ application with $83.72 \%$ (Fig. 1). Chitrampalan et al. (2008) investigated the action of Trichoderma harzianum (Plantshield), Gliocladium virens (Soilgard), Coniothyrium minitans (Contans), Bacillus subtilis (Companion) biological preparations and the fungicide with Iprodione (Rovral) active agent in control of Sclerotinia sclerotiorum and $S$. minor disease agents that are destructive in lettuce cultivation. It was reported in the study that single applications of biological preparations and fungicide were not effective in the control of disease agents. It was reported that twice Coniothyrium minitans application during the planting and post-thinning periods reduced Sclerotinia sclerotiorum incidence and improved the yield. There was no significant decrease in disease rates in other biocontrol products. The study findings demonstrated that Coniothyrium minitans (Contans) was the most effective application in control of $S$. sclerotiorum induced white mold disease in lettuce. These findings were consistent with the present study. Similar to the current study, it was reported that successful results were achieved with twice application of biologic preparations in disease control in several studies (Chitrampalam et al., 2010). The effects of single application of Contans (Coniothyrium minitans) and in combination with Radix (Trichoderma asperellum and Trichoderma gamsii), Kraft pine lignin and Rovral were compared in disease control in naturally S. Sclerotiorum-infected lettuce greenhouses. Single application of $4 \mathrm{~kg} / \mathrm{ha}$ Contans had a negative effect on sclerotia viability, however did not reduce the disease incidence in lettuce. In the study, the highest impact on disease rate in different harvest periods was obtained in the third harvest and the lowest disease rate was obtained with Contans + lignin application $(4.7 \%)$. In the study, this was followed by Contans + lignin + Radix application with a $6.7 \%$ rate among biological applications when compared to chemical combinations. In the study, it was reported that the significant decrease in sclerotia viability that was observed in the soil treated with Contans could be due to the long incubation time, repeated application, different climatic conditions and the use of different varieties (Van Bendeneden et al., 2010).

Commercial Luna was successful as a standard fungicide in the control of Sc in lettuce trial fields. However, significant losses in lettuce due to white mold despite excessive fungicide applications continue today. Chitrampalam et al. (2011) investigated the effectiveness of $C$. minitans (Contans) application in different doses 
and times on white mold in lettuce in 2011. In field experiments, lower sclerotia was detected in all Contans applications when compared to Endura chemical fungicide and control applications. It was found that the disease rate was low in other applications similar to Endura fungicide application plots. As a result of the study, it was reported that Contans use to lower the sclerotia count in the soil was the key to long-term success in white mold disease control and Endura fungicide application was also useful to protect the plant from disease infection. The findings of the study were consistent with our findings.

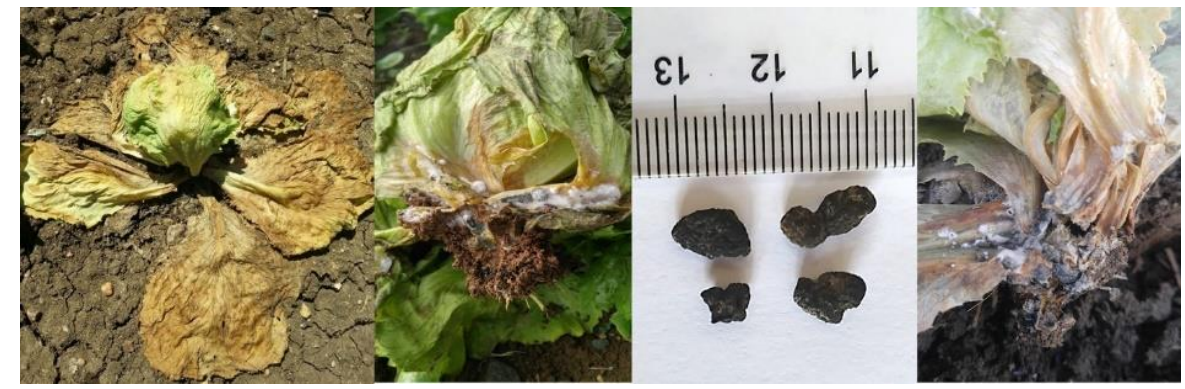

Figure 1. Sclerotinia sclerotiorum which causes white mold disease in lettuce, black sclerotia, white mycelium and brown, soft, watery decays in lettuce leaf in control plant

In our study, the impact rates of the applications in disease control demonstrated that the highest effect was obtained with Luna chemical application in the field experiments (Table 2). In both field experiments where the biological preparations were applied alone and in combination, hopeful results that may be an alternative to the success of the chemical applications were obtained. Thus, the highest effect was obtained with $\mathrm{C} 4$ $+\mathrm{TH}$ application (80-86.05\%), while the lowest effect was obtained with TH application (54-60.47\%). The low variation among the effects of biological agents on the disease in both experiment fields was due to the fact that, as stated by Howel (2003), the biological control factor was dependent on the pathogen and host plant interaction and the presence of other microorganisms in soil microflora. The studies on parasite infection of Trichoderma isolates and S. sclerotiorum induced sclerotia and on reduction of apothecia concentration were mostly conducted in greenhouse and laboratory conditions (Inbar et al., 1996; Matroudi et al., 2009; Smolinska et al., 2016). In a study conducted in greenhouse, Inbar et al. (1996) determined that Trichoderma harzianum applications reduced white mold disease by $46-72 \%$ in lettuce when compared to control plants. However, the number of studies on antagonistic activity of Trichoderma in field conditions is quite limited (Knudsen et al., 1991; Zeng et al., 2012a; Geraldine et al., 2013). The effects of biological control agents Coniothyrium minitans CON/M/91-08, Trichoderma harzianum T-22, Bacillus subtilis QST 713 and Streptomyces lydicus WYEC 108 on Sclerotinia sclerotiorum production and sclerotia survival were investigated under controlled conditions. In the study, it was determined that $C$. minitans decreased apothecia and sclerotia by $81.2 \%$ and $50 \%$, respectively, while Trichoderma harzianum decreased apothecia and sclerotia by $80.5 \%$ and $31.7 \%$, respectively (Zeng et al., 2012b). Budge and Whipps (1991) investigated the effects of Coniothyrium minitans, Trichoderma harzianum (HH3) and Trichoderma sp (Bl) in Sclerotinia sclerotiorum induced disease control in two lettuce greenhouses and in a celery greenhouse. It was found that single C. Minitas applications reduced white mold 
disease in lettuce and improved marketable yield. In the study, it was found that the tested Trichoderma species had no significant effect on the disease and had virtually no effect on the survival of sclerotia. In the study, the lowest S. sclerotiorum disease rate in lettuce was obtained with C. minitas application (48.2-50.3\%) in the first and second harvest when compared to control (90.3-58.5\%), and it was followed by T. harzianum Rifai (HH3) isolate application (62.8-56.2\%). These findings were similar to the present study findings. In the study, the significant gradual reduction of sclerotia count in time, especially in the second lettuce crop, led to the idea that sclerotes caused an attack by natural microflora and micro-fauna. Huang et al. (2000) reported that $C$. minitans spore suspension spray during bean plant flowering reduced white mold disease rate by $56 \%$. In the study conducted by application of $C$. minitans on the upper soil before soybean seeding, it was determined that the application reduced the $S$. sclerotiorum disease severity index by $68 \%$ and the sclerotia count in the soil by $95.3 \%$ (Zeng et al., 2012a).

In the present study, it was concluded that combined use of Contans $(4 \mathrm{~kg} / \mathrm{da})$ + Trichoderma harzianum $(50 \mathrm{~g} / 100 \mathrm{lt}, \mathrm{T}-22)$ that included Coniothyrium minitans biological agent could an alternative to chemical applications in control of the white mold disease that leads to losses in market value of the lettuce crop, as well as significant yield losses (Fig. 2).

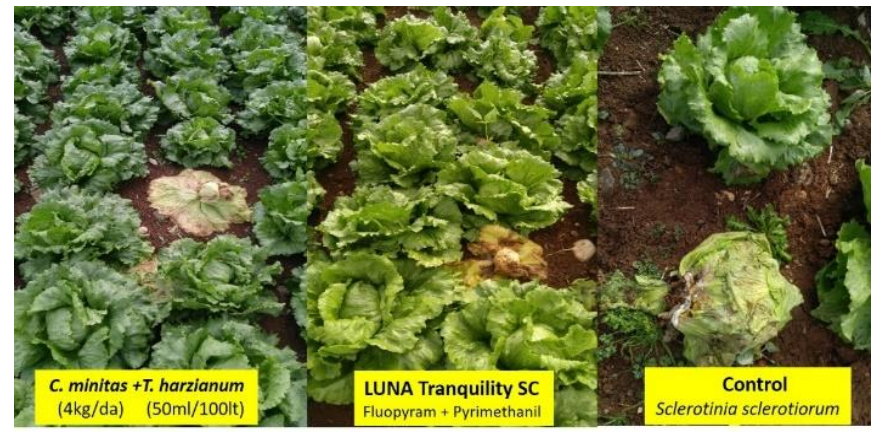

Figure 2. An image from the most effective C. minitas and TH applications to control white mold disease in lettuce parcel

\section{Determination of the effect of the applications on the yield and certain physical properties}

The data on the effects of the single and combined use of Coniothyrium minitans and Trichoderma harzianum biological preparations in control of SC disease agent that causes significant yield losses in lettuce cultivation on marketable mean head weight $(\mathrm{kg} / \mathrm{plant})$, yield $(\mathrm{kg} / \mathrm{da})$, root weight $(\mathrm{g})$, root length $(\mathrm{cm})$ and crown diameter $(\mathrm{mm})$ of Iceberg lettuce cultivar are presented in Table 3.

Analysis of the lettuce plant yield demonstrated that KA and DE resulted in significant yield increases in lettuce cultivation. The increase in yield ranged between $13-34 \%$ and $16-27 \%$ in the experimental fields and the highest increase was obtained with $7560-6701 \mathrm{~kg} / \mathrm{da} \mathrm{C} 4+\mathrm{TH}$ application and the lowest was obtained with control with $5640-5240 \mathrm{~kg} / \mathrm{da}$. An important parameter in yield and quality in lettuce cultivation is marketable head weight. The effects of biological preparation applications on marketable head weight were found to be statistically significant. In the study, an increase was observed in marketable head weight with all combined Coniothyrium minitans and Trichoderma harzianum applications. The highest marketable head weight 
was obtained with combined $\mathrm{C} 4+\mathrm{TH}(1.260-1.117 \mathrm{~kg} / \mathrm{plant})$ application in both experimental plots, followed by Luna chemical application (1.257-1.107 kg/plant). Chitrampalam et al. (2008) did not report statistically significant differences between the lettuce head weigh and yield with Trichoderma harzianum (Plantshield), Gliocladium virens (Soilgard), Coniothyrium minitans (Contans) and Bacillus subtilis (Companion) biological preparation applications used to control S. sclerotiorum in lettuce. However, in both lettuce locations, it was found that the twice Coniothyrium minitans application in planting and thinning periods effectively suppressed $\mathrm{S}$. sclerotiorum, thus indirectly increasing the lettuce head weight. These findings were followed by Gliocladium virens, Trichoderma harzianum and Bacillus subtilis applications. These findings were consistent with the findings of our study.

Under field conditions, Knudsen et al. (1991) found that Trichoderma isolates contributed to an increase in lettuce head weight by releasing Trichoderma isolates to the soil for $S$. sclerotiorum sclerotia infection, and the experiments reduced the infection by $100 \%$. In a study, Bal and Altıntaş (2008) investigated the effects of Trichoderma harzianum on lettuce plant development. It was determined that $T$. harzianum applications did not lead to a significant increase in lettuce yield and root growth. Rabeendran et al. (2000) reported that two Trichoderma harzianum isolates applied to the lettuce plant in the field increased the yield significantly. It was reported in several studies that various Trichoderma species increased the growth, development and plant yields at different rates in studies conducted with different plants. Trichoderma species are not only found on plant root surfaces, but also in various parts of the plant endophytically. It was also reported that these endophytic species promoted plant growth and protected the plant against biotic and abiotic factors (Bae et al., 2009 Poldma et al., 2002; Altıntaş and Bal, 2005; Elad et al., 2006; Druzhinina et al., 2011).

In the present study, the effects of single and combined Coniothyrium minitans and Trichoderma harzianum biological agent application in lettuce cultivation were statistically significant on lettuce root weight, root length and root diameter. When compared to the control application, the root weight increased in all applications in both experimental plots. The highest root weight was obtained in the KA plot with $\mathrm{C} 4+\mathrm{TH}$ and Luna applications $(45.59 \mathrm{~g}-44.87 \mathrm{~g})$ and in the DE plot, with $\mathrm{C} 3+\mathrm{TH}$ and TH 3 $+\mathrm{TH}$ and $\mathrm{C} 4+\mathrm{TH}$ applications $(48.47 \mathrm{~g}-46.59 \mathrm{~g})$.

When compared to the control application, the highest increase in the root length in all applications in both experimental plots was 32-31\%. The highest root length measurements were $18.82 \mathrm{~cm}$ with Luna and $18.61 \mathrm{~cm}$ with $\mathrm{C} 4+\mathrm{TH}$ applications. In DE parcel, the highest root length of $18.80 \mathrm{~cm}$ was obtained with combined $\mathrm{C} 4+\mathrm{TH}$ biological preparation application, followed by $\mathrm{C} 3+\mathrm{TH}$ application with $18.21 \mathrm{~cm}$. Yedidia et al. (2001) reported that Trichoderma harzianum increased the root length in cucumber plant by $75 \%$ and root area by $95 \%$ in a study they conducted. In another study on the effects of Trichoderma harzianum on the development of lettuce plant, it was determined that $\mathrm{TH}$ application did not significantly increase the root growth in lettuce (Bal and Altintas, 2008).

The effects of the single and combined use of biological preparations compared to the control and chemical application (Table 2) demonstrated that the application led to an increase in crown diameter of the lettuce in KA and DE plots by $18 \%$ to $36 \%$, respectively. The increase in crown diameter in both experimental plots was obtained in all plots where Coniothyrium minitans and Trichoderma harzianum were applied in combination. The highest increase in KA plot in crown diameter was obtained with $\mathrm{C} 4$ 
+ TH and $\mathrm{C} 3+\mathrm{TH}$ applications $(31.44 \mathrm{~mm}-31.35 \mathrm{~mm})$, while it was obtained with $\mathrm{C} 4$ $+\mathrm{TH}$ application $(37.30 \mathrm{~mm})$ in DE plot, followed by combined C3 + TH application $(35.48 \mathrm{~mm}$ ). The crown diameter was determined as $26.54-27.29 \mathrm{~mm}$ in the two experimental plots, respectively.

Table 2. Lettuce white mold disease of applications in the control against the disease incidence and effect

\begin{tabular}{c|c|c|c|c}
\hline \multirow{2}{*}{ Treatments } & \multicolumn{2}{|c|}{ Experiment area KA } & \multicolumn{2}{c}{ Experiment area DE } \\
\cline { 2 - 5 } & Disease incidence (\%) & \% Effect & Disease incidence (\%) & \% Effect \\
\hline C2 & $26.25 \mathrm{~cd}$ & 58.00 & $20.00 \mathrm{~b}$ & 62.79 \\
C3 & $17.50 \mathrm{abc}$ & 72.00 & $10.00 \mathrm{a}$ & 81.40 \\
$\mathrm{C} 4$ & $16.25 \mathrm{abc}$ & 74.00 & $8.75 \mathrm{a}$ & 83.72 \\
TH & $28.75 \mathrm{~d}$ & 54.00 & $21.25 \mathrm{~b}$ & 60.47 \\
$\mathrm{C} 2+\mathrm{TH}$ & $25.0 \mathrm{bcd}$ & 56.00 & $11.25 \mathrm{a}$ & 79.07 \\
$\mathrm{C} 3+\mathrm{TH}$ & $15.00 \mathrm{ab}$ & 76.00 & $8.75 \mathrm{a}$ & 83.72 \\
$\mathrm{C} 4+\mathrm{TH}$ & $12.50 \mathrm{a}$ & 80.00 & $7.50 \mathrm{a}$ & 86.05 \\
Luna & $11.25 \mathrm{a}$ & 82.00 & $6.25 \mathrm{a}$ & 88.37 \\
Control & $62.50 \mathrm{e}$ & - & $53.75 \mathrm{e}$ & - \\
\hline Lsd 0.05 & 9.703 & & 7.463 & \\
\hline
\end{tabular}

C2: Contans application of $2 \mathrm{~kg} / \mathrm{ha}$; C3: Contans application of $3 \mathrm{~kg} / \mathrm{ha}$; C4: Contans application of $4 \mathrm{~kg} / \mathrm{ha}$; TH: Trichoderma harzianum application of $50 \mathrm{~g} / 100 \mathrm{lt}$; Luna application of $100 \mathrm{ml} / \mathrm{da}$; Control: only water (without biological preparat and fungicide)

Table 3. Effect of applications and some plant physical properties

\begin{tabular}{|c|c|c|c|c|c|c|c|c|c|c|}
\hline \multirow[t]{2}{*}{ Treatments } & \multicolumn{2}{|c|}{$\begin{array}{c}\text { Marketable } \\
\text { mean head } \\
\text { weight } \\
(\mathrm{kg} / \mathrm{plant})\end{array}$} & \multicolumn{2}{|c|}{$\begin{array}{l}\text { Yield } \\
\text { (kg/da) }\end{array}$} & \multicolumn{2}{|c|}{$\begin{array}{l}\text { Root weight } \\
\text { (g) }\end{array}$} & \multicolumn{2}{|c|}{$\begin{array}{l}\text { Root length } \\
\text { (cm) }\end{array}$} & \multicolumn{2}{|c|}{$\begin{array}{l}\text { Root collar } \\
\text { diameter } \\
\quad(\mathbf{m m})\end{array}$} \\
\hline & KA & DE & KA & & KA & $\mathbf{E}$ & $\mathbf{K A}$ & E & KA & DE \\
\hline $\mathrm{C} 2$ & $1.063 \mathrm{c}$ & $13 b$ & $75 \mathrm{c}$ & $75 \mathrm{ab}$ & 36.13de & $37.79 \mathrm{~d}$ & $8.43 \mathrm{abc}$ & $15.04 \mathrm{e}$ & 8.84de & $32.10 \mathrm{e}$ \\
\hline $\mathrm{C}^{3}$ & $117 \mathrm{bc}$ & $1.043 \mathrm{ab}$ & $02 \mathrm{bc}$ & 6260ab & | ז02 30 & $40.60 \mathrm{c}$ & 18.1 & $16.32 \mathrm{~cd}$ & & \\
\hline $\mathrm{C} 4$ & $20 b c$ & $27 \mathrm{ab}$ & $6720 \mathrm{bc}$ & 6160ab & $36.52 \mathrm{c}$ & $40.73 c$ & 18.57ab & $17.41 \mathrm{~b}$ & $29.60 \mathrm{c}$ & 34 \\
\hline $\mathrm{TH}$ & $167 \mathrm{~b}$ & $1.073 \mathrm{ab}$ & $7002 b$ & $6435 \mathrm{ab}$ & $40.93 b$ & $36.95 \mathrm{~d}$ & 17.83abc & $17.34 \mathrm{~b}$ & $30.52 b$ & 31 \\
\hline $\mathrm{C} 2+\mathrm{T}$ & $1.153 b$ & 1.05 & $6920 \mathrm{~b}$ & $6300 \mathrm{ab}$ & $35.24 \mathrm{de}$ & $38.52 \mathrm{~cd}$ & $17.46 \mathrm{c}$ & $16.08 \mathrm{~d}$ & $27.69 \mathrm{f}$ & 33 \\
\hline$-\mathrm{TH}$ & $1.113 b c$ & $1.057 \mathrm{ab}$ & $6678 b c$ & $6340 \mathrm{ab}$ & $40.29 b c$ & $48.47 \mathrm{a}$ & $17.53 b c$ & $18.21 \mathrm{a}$ & $31.35 \mathrm{a}$ & $35.48 \mathrm{~b}$ \\
\hline $\mathrm{TH}$ & $1.260 \mathrm{a}$ & $1.117 \mathrm{a}$ & $7560 \mathrm{a}$ & $6701 \mathrm{a}$ & $45.59 \mathrm{a}$ & $46.59 \mathrm{ab}$ & $18.61 \mathrm{a}$ & $18.80 \mathrm{a}$ & $31.44 \mathrm{a}$ & $37.30 \mathrm{a}$ \\
\hline LUNA & $1.257 \mathrm{a}$ & $1.107 \mathrm{ab}$ & $7542 \mathrm{a}$ & 6640ab & $44.87 \mathrm{a}$ & $44.20 \mathrm{~b}$ & $18.82 \mathrm{a}$ & $17.03 b c$ & $28.58 \mathrm{e}$ & $36.09 \mathrm{~b}$ \\
\hline C & $0.940 \mathrm{~d}$ & $0.873 \mathrm{c}$ & $5640 \mathrm{~d}$ & $5240 \mathrm{c}$ & $34.53 \mathrm{e}$ & $36.04 d$ & $14.17 \mathrm{~d}$ & $14.31 \mathrm{e}$ & $26.54 \mathrm{~g}$ & $27.29 \mathrm{~g}$ \\
\hline Lsd 0.05 & 0.057 & 0.084 & 341.984 & 508.269 & 1.641 & 2.670 & 0.959 & 0.754 & 0.704 & \begin{tabular}{|l}
0.729 \\
\end{tabular} \\
\hline
\end{tabular}

C2: Contans application of $2 \mathrm{~kg} / \mathrm{ha}$; C3: Contans application of $3 \mathrm{~kg} / \mathrm{ha}$; C4: Contans application of $4 \mathrm{~kg} / \mathrm{ha}$; TH: Trichoderma harzianum application of $50 \mathrm{~g} / 100 \mathrm{lt}$; Luna application of $100 \mathrm{ml} / \mathrm{da}$; Control: only water (without biological preparat and fungicide) 


\section{Discussion}

Although certified chemical fungicides are available in Turkey, especially in control of white mold disease in lettuce, the number of disinfestations or doses are increased due to the severity of the disease. This does not improve the control success, as well as causing environmental pollution and residual product threatens human health and disrupts the balance of nature. The emergence of plant resistance to agents used in these products is one of the most important problems induced by chemical control. The best way to limit the application of pesticides used in Sclerotinia sclerotiorum control in lettuce is cultivation of resistant varieties. However, due to the specific character of the disease induced by this pathogen, breeding programs had a limited success (Uloth et al., 2014). Today, in the absence of disease-resistant varieties, the research on environmentfriendly methods such as biological methods have intensified for long-term destruction of Sclerotinia sclerotiorum in the soil.

In this context, the present study findings suggested that the use of Contans that contains Coniothyrium minitans biological agent $(4 \mathrm{~kg} / \mathrm{da})+$ Trichoderma harzianum (50 g/100 lt/T-22) combination could be an alternative to chemicals in control of white mold disease that leads to market value losses and significant losses in the yield, especially in highly infected fields in lettuce cultivation. It was observed that several studies were conducted worldwide on biological control of white mold disease induced by Sclerotinia sclerotiorum disease agent. In both field and greenhouse experiments conducted to determine the impact of Coniothyrium minitans as a biological control agent against white mold disease, it was determined that single use of the biological preparations were not sufficient, however twice application of the agent significantly to reduces the severity of the disease (Chitrampalam et al., 2008).

The application of biological methods to control plant pathogens is known to be safer for the environment when compared to the use of pesticides. Chemical control of Sclerotinia sclerotiorum is quite difficult since ascospores can infect any part of the lettuce head. Also, it is more difficult to prevent after the presence of apothecia in the plant (Patterson and Grogan, 1985). Biological control methods may be partially sufficient to completely reduce the populations of plant disease pathogens. The complete destruction of the disease in the soil can only be possible if the pathogen concentration is already low in the soil. The most successful method, thus, is the combined application of antagonistic fungi with strong parasitic properties such as $C$. minitas and Trichoderma genus fungi (Smolinska and Kowalska, 2018).

However, in order to ensure a long-term and effective biological control in soilborne diseases such as plant pathogens, especially Sclerotinia sclerotiorum, crop rotation, the use of resistant varieties, solarization (soil disinfection) and taking all cultural measures in combination are important (Subbarao, 1998; Villata et al., 2012; Çolak Ates et al., 2019). Therefore, an integrated approach that adopts multiple control measures could provide sustainable control against sclerotia. In the success of such a strategy, selection of agricultural and crop management practices that reduces the accumulation of pathogen inoculum and the risk of disease propagation is important (Koike et al., 2003). 


\section{Conclusion}

In this study, it was concluded that Contans containing Coniothyrium minitans biological agent $(4 \mathrm{~kg} / \mathrm{da})+$ Trichoderma harzianum $(50 \mathrm{~g} / 100 \mathrm{lt} / \mathrm{T}-22)$ could be an effective alternative to chemicals in the control against white mold disease by Sclerotinia sclerotiorum. Furthermore, S. sclerotiorum in areas where the risk of disease is very high, in order to prevent high $S$. sclerotiorum levels, very detailed control studies with biological preparations and existing fungicide applications and at different application doses are required.

Acknowledgements. The authors are so grateful to General Directorate of Agricultural Research and Policies (project number TAGEM-BS-15/09-10/02-08 (04)) for financial support.

\section{REFERENCES}

[1] Adams, P. B., Ayers, W. A. (1979): Ecology of Sclerotinia species. - Phytopathology 69: 896-899.

[2] Aksay, A., Biçici, M., Çınar, Ö. (1991): Beyaz çürüklük etmeni Sclerotinia sclerotiorum (Lib) de Bary’a karşı antagonistlerin belirlenmesi. - Çukurova Üniv. Ziraat Fak., Derg. 6(2): 55-62.

[3] Altıntas, S., Bal, U. (2005): Application of Trichoderma harzianum increases yield in cucumber (Cucumis sativus) grown in an unheated glasshouse. - J. Appl. Horticulture 7: $25-28$.

[4] Anonymous (2017): FAOSTAT. - www.fao.org.

[5] Bae, H., Sicher, R. C., Kim, M. S., Kim, S. H., Strem, M. D., MeInice, R. L., Bailey, B. A. (2009): The beneficial endophyte Trichoderma hamatum isolate DS 219b promotes growth and delays the onset of the drought response in Theobroma cacao. - Journal of Experimental Botany 60: 3279-3295.

[6] Bal, U., Altintas, S. (2008): Effects Of Trichoderma harzianum on lettuce in protected cultivation. - Journal of Central European Agriculture 9(1): 63-70.

[7] Budge, S. P., Whipps, J. M. (1991): Glasshouse trials of Coniothyrium minitans and Trichoderma species for the biological control of Sclerotinia sclerotiorum in celery and lettuce. - Plant Pathol 40: 59-66.

[8] Budge, S. P., Whipps, J. M. (2001): Potential for integrated control of Sclerotinia sclerotiorum in glasshouse lettuce using Coniothyrium minitans and reduced fungicide application. - Phytopathology 91: 221-227.

[9] Budge, S. P., McQuilken, M. P., Fenion, J. S., Whipps, J. M. (1995): Use of Coniothyrium minitans and Gliocladium virens for biological control of Sclerotinia sclerotiorum in glasshouse lettuce. - Biol Control 5: 513-522.

[10] Çarkac1, N., Maden, S. (1986): Host speciation, antagonists and parasites of Sclerotinia sclerotiorum (Lib.) de Bary. - J. Turk. Phytopath. 15: 113-122.

[11] Celar, F. (2002): Influence of root exudates of different plant seedlings on mycelial growth of antagonistic fungi Trichoderma spp. and Gliocladium roseum. Zb. - Biotech. Fak. Univ. Ljublj. Kmet. 79-2: 343-348.

[12] Chitrampalam, P., Figuli, P. J., Matheron, M. E., Subbarao, K. V., Pryor, B. M. (2008): Biocontrol of lettuce drop caused by Sclerotinia sclerotiorum and S. minor in desert agroecosystems. - Plant. Dis. 92: 1625-1634.

[13] Chitrampalam, P., Cox, C. A., Turini, T. A., Pryor, B. M. (2010): Efficacy of Coniothyrium minitans on lettuce drop caused by $S$. minor in desert agroecosystem. Biological Control 55: 92-96. 
[14] Chitrampalam, P., Wu, B. M., Koike, S. T., Subbarao, K. V. (2011): Interactions between Coniothyrium minitans and Sclerotinia minor affect biocontrol efficacy of $C$. Minitans. Phytopathology 101(3): 358-366.

[15] Clarkson, J. P., Phelps, K., Whipps, J. M., Young, C. S., Smith, J. A., Watling, M. (2004): Forecasting Sclerotinia disease on lettuce: toward developing a prediction model for carpogenic germination of sclerotia. - Phytopathology 94: 268-279.

[16] Clarkson, J. P., Fawcett, L., Anthony, S. G., Young, C. (2014): A model for Sclerotinia sclerotiorum infection and disease development in lettuce, based on the effects of temperature, relative humidity and ascospore density. - PLoS One 9(4): e94049.

[17] Çolak, A. (2007): Biocontrol products for use against tomato diseases. - II. International Symposium on Tomato Diseases, 8-12 October, Kuşadas1/İzmir, Turkey.

[18] Çolak, A., Biçici, M. (2013): Integrated disease management of fusarium crown and root rot of greenhouse-grown tomato in eastern Mediterranean region of Turkey. - Journal of Agricultural Sciences 19: 89-100.

[19] Çolak, A. A., Fidan, H. (2018): Identification of white rot and the most common virus

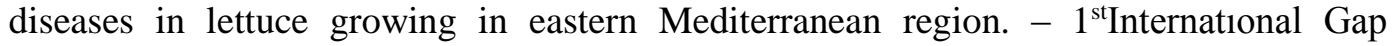
Agriculture and Livestock Congress, 25-27 April 2018, Şanliurfa, Turkey

[20] Çolak Ates, A., Fidan, A., Karacaoğlu, M., Dasgan, H. Y. (2019): The identification of the resistance levels of Fusarium oxysporum f. sp. radicis-lycopersici and Tomato yellow leaf curl viruses in different tomato genotypes through traditional and molecular methods. - Applied Ecology and Environmental Research 17(2): 2203-2218.

[21] Çoşkun, B. Ç., Yıldız, F. (2017): Biological control of white mold disease (Sclerotinia sclerotiorum) on lettuce by using fungal antagonists. - J. Turk. Phytopath. 46(1): 1-14.

[22] Druzhinina, I. S., Seidl-Seiboth, V., Herrera-Estrella, A., Horwitz, B. A., Kenerley, C. M., Monte, E., Mukherjee, P. K., Zeilinger, S., Grigoriev, I., Kubicek, C. P. (2011): Trichoderma - the genomics of opportunistic success. - Nature Reviews Microbiology 9: 749-759.

[23] Elad, Y., Chet, I., Henis, Y. (2006): Biological control of Rhizoctonia solani in strawberry fields by Trichoderma harzianum. - Plant and Soil 60: 245-254.

[24] Elias, L. M., Domingues, M. V. P. F., Moura, K. E., Salomão, D., Harakava, R., Patricio, F. R. A. (2016): Selection of Trichoderma isolates for biological control of Sclerotinia minor and S. sclerotiorum in lettuce. - Summa Phytopathologica 42(3): 216-221.

[25] Elsheshtawi, M., Maged, T. E., Shaban, R. S., Ali, H. B., Arif, A. M., Dikshit, G., Aref, S. M., Elgorban, A. M. (2017): Integrated control of white rot disease on beans caused by Sclerotinia sclerotiorum using Contans and reduced fungicides application. - Saudi Journal of Biological Sciences 24: 405-409.

[26] Geraldine, A. M., Lopes, F. A. C., Carvalho, D. D. C., Barbosa, E. T., Rodrigues, A. F., Brandao, R. S., Ulhoa, C. J., Junior, M. L. (2013): Cell wall-degrading enzymes and parasitism of sclerotia are key factors on field biocontrol of white mold by Trichoderma spp. - Biol Control 67: 308-316.

[27] Gerlagh, M., Goossen-van de Geijn, H. M., Fokkema, N. J., Vereijken, P. F. G. (1999): Long-term biosanitation by application of Coniothyrium minitans on Sclerotinia sclerotiorum infected crops. - Phytopathology 89: 141-147.

[28] Giczey, G., Kerenyi, Z., Fulop, L., Hornok, L. (2001): Expression of cmg1, and exo-beta1,3-glucanase gene from Coniothyrium minitans, increases during sclerotial parasitism. Appl. Environ. Microbiol. 67: 865-871.

[29] Hao, J. J., Subbarao, K. S. (2005): Comparative analyses of lettuce drop epidemics caused by Sclerotinia minor and S. sclerotiorum. - Plant Dis. 89: 717-725.

[30] Howell, C. R. (2003): Mechanisms employed by Trichoderma species in the biological control of plant diseases: the history and evolution of current concepts. - Plant Disease 87: 4-10. 
[31] Huang, H. C., Patterson, C. L., Grogan, R. G. (1985): Differences in epidemiology and control of lettuce drop caused by Sclerotinia minor and S. sclerotiorum. - Plant Disease St. Paul 69: 766-770.

[32] Inbar, J., Menendez, A., Chet, I. (1996): Hyphal interaction between Trichoderma harzianum and Sclerotinia sclerotiorum and its role in biological control. - Soil Biol. Biochem. 28: 757-763.

[33] Jones, E. E., Whipps, J. M. (2002): Effect of inoculums rates and sources of Coniothyrium minitans on control of Sclerotinia sclerotiorum disease in glasshouse lettuce. - Eur J Plant Pathol 108: 527-538.

[34] Karman, M. (1971): Bitki Koruma Araştırmalarında Genel Bilgiler Kitabı. - T. C. Tarım Bakanlığı Zirai Mücadele ve Zirai Karantina Genel Müdürlüğü Yayınları. Bornova/ İzmir. Ağustos 1971.

[35] Knudsen, G. R., Eschen, D. J., Dandurand, L. M. (1991): Potential for biocontrol of $S$. sclerotiorum through colonization of sclerotia by T. harzianum. - The American Phythopathological Society. Plant Dis. 75(5): 466-470.

[36] Koike, S. T., Subbarao, K. V., Davis, R. M., Turini, T. A. (2003): Vegetable Disease Caused by Soil Borne Pathogens. - University of California, Division of Agriculture and Natural Resources, Commercial Greenhouse Vegetable Handbook, Publication 21575, pp. 1-13.

[37] Lopez-Mondejar, R., Ros, M., Pascual, J. A. (2011): Mycoparasitism-related genes expression of Trichoderma harzianum isolates to evaluate their efficiency as biological control agents. - Biol Control 56: 59-66.

[38] Matheron, M. E., Porchas, M. (2003): Vegetable Crops 1997-2003. - The University of Arizona Cooperative Extension Search Reports, Tucson, AZ.

[39] Matroudi, S., Zamani, M. R., Motallebi, M. (2009): Antagonistic effects of three species of Trichoderma sp. on Sclerotinia sclerotiorum, the causal agent of canola stem rot. Egypt J Biol 11: 37-44.

[40] Mert-Türk, F., Mermer, D. (2004): Çanakkale'de Örtüaltında Yetiştirilen Marullarda Sclerotinia sclerotiorum un Yaygınlığının ve Misel Uyum Gruplarının Saptanması. MKU. - Ziraat Fakültesi Dergisi 9(1-2): 1-8.

[41] Naher, L., Yusuf, U. K., Habib, S. H., Ky, H., Siddiquee, S. (2018): Mycoparasitsm activity of Trichoderma harzianum associated with chitinase expression against Ganoderma boninense. - Pak. J. Bot. 50(3): 1241-1245.

[42] Poldma, P., Albrecht, A., Merivee, A. (2002): Influence of fungus Trichoderma viride on the yield of cucumber in greenhouse conditions. - Proc. Conference on Scientific Aspects of Organic Farming. Jelgava, Latvia 21-22 March 2002, pp. 176-180.

[43] Porter, I., Pung, H., Villalta, O., Crnov, R., Stewart, A. (2002): Development of biological controls for Sclerotinia diseases of horticultural crops in Australasia. - 2nd Australasian Lettuce Industry Conference, 5-8 May 2002, University of Queensland, Gatton Campus.

[44] Purdy, L. H. (1979): Sclerotinia sclerotiorum - history, diseases and symptomatology, host range, geographic distribution, and impact. - Phytopathology 69: 875-880.

[45] Qualhato, F. T., Cardoso, L. A. F., Steindorft, S. A., Brandao, S. R., Jesuino, A. S. R., Ulhoa, J. C. (2013): Mycoparasitism studies of Trichoderma species against three phytopathogenic fungi: evaluation of antagonism and hydrolytic enzyme production. Biotechnol. Letter 35: 1461-1468.

[46] Rabeendran, N., Moot, D. J., Jones, E. E., Stewart, A. (2000): Inconsistent growth promotion of cabbage and lettuce from Trichoderma isolates. - N. Z. Plant Prot. 53: 143146.

[47] Patterson, C. L., Grogan, R. G. (1985): Differences in epidemiology and control of lettuce drop caused by Sclerotinia minor and S. Sclerotiorum. - Plant Disease 69: 766-770.

[48] Smolinska, U., Kowalska, B. (2018): Biological control of the soil-borne fungal pathogen Sclerotinia sclerotiorum, a review. - Journal of Plant Pathology 100: 1-12. 
[49] Smolinska, U., Kowalska, B., Kowalczyk, W., Szczech, M., Murgrabia, A. (2016): Eradication of Sclerotinia sclerotiorum sclerotia from soil using organic waste materials as Trichoderma fungi carriers. - J Horticultural Res 24: 101-110

[50] Soylu, S., Sertkaya, E., Üremiş, I., Bozkurt, A., Kurt., Ş. (2017): Prevalence and incidence of important disease agents, insects and weed species in lettuce (Lactuca sativa L.) growing fields in Hatay Province. - Journal of Agricultural Faculty of Mustafa Kemal University 22(1): 23-33.

[51] Subbaro, K. V. (1998): Progress toward integrated management of lettuce drop. - Plant Dis. 82: $1068-1078$.

[52] Spadaro, D., Gullino, M. L. (2005): Improving the efficacy of biocontrol agents against soilborne pathogens. - Crop Prot. 24: 601-613.

[53] Subbarao, K. V. (1998): Progress toward integrated management of lettuce drop. - Plant Dis. 82: 1068-1078.

[54] Tomprefa, N., Hill, R., Whipps, J., McQuilken, M. (2011): Some environmental factors affect growth and antibiotic production by mycoparasite Coniothyrium minitans. Biocontrol Sci Tech 21: 721-731.

[55] Trutmann, P., Keane, P. J., Merriman, P. R. (1980): Reduction of sclerotial inoculums of Sclerotinia sclerotiorum with Coniothyrium minitans. - Soil Biol Biochem 12: 461-465

[56] Turner, G. J., Tribe, H. T. (1976): On Coniothyrium minitans and its parasitism of Sclerotinia species. - Transactions of the British Mycological Society 66: 97-105.

[57] Tüzel, Y., Oztekin, G. B., Duyar, H., Eşiyok, D., Kılıç, G. O., Anaç, D., Kayıkçıŏglu, H. H. (2011): Effects of some organic fertilizers and agryl cover on yield, quality and leaf nutrient content and soil productivity in organic lettuce growing. - Journal of Agricultural Sciences 17: 190-203.

[58] Uloth, M., You, M. P., Finnegan, P. M., Banga, S. S., Yi, H., Barbetti, M. J. (2014): Seedling resistance to Sclerotinia sclerotiorum as expressed across diverse cruciferous species. - Plant Dis 98: 184-190.

[59] Van Beneden, S., Leenknegt, I., Franca, S. C. and Hofte, M. (2010): Improved control of lettuce drop caused by Sclerotinia sclerotiorum using Contans combined with lignin or a reduced fungicide application. - Crop Prot. 29(2): 7.

[60] Villalta, O. N., Wite, D., Hunt, J., Stewart, A., Porter, I. J. (2012): Biological control of Sclerotinia minor on lettuce using Trichoderma and Coniothyrium species. - Acta Horticulturae 944: 51-58.

[61] Vinale, F., Sivasithamparam, K., Ghisalberti, E. L., Marra, R., Woo, S. L., Lorito, M. (2008): Trichoderma-plant-pathogen interactions. - Soil Biol Biochem 40: 1-10

[62] Whipps, J. M., Budge, S. P. (1990): Screening for sclerotial mycoparasites of Sclerotinia sclerotiorum. - Mycological Res. 94: 607-661.

[63] Yedidia, I., Srivastava, A. K., Kapulnik, Y., Chet, I. (2001): Effect of Trichoderma harzianum on microelement concentrations and increased growth of cucumber plants. Plant Soil 235: 235-242.

[64] Young, C. S., Smith, J. A., Watling, M., Clarkson, J. P., Whipps, J. M. (2001): Environmental Conditions Influencing Apothecial Production and Lettuce Infection by Sclerotinia sclerotiorum in Field Conditions. - In Young, C., Hughes, K. (eds.) Proceedings of the 6th International Sclerotinia Workshop. York, pp. 181-182.

[65] Zeng, W., Kırk, W., Hao, J. (2012a): Field management of Sclerotinia stem rot of soybean using biological control agents. - Biol Control 60: 141-147.

[66] Zeng, W., Wang, D., Kırk, W., Hao, J. (2012b): Use of Coniothyrium minitans and other microorganisms for reducing Sclerotinia sclerotiorum. - Biol Control 60: 225-232. 